\title{
A review of rare Scottish pot beetles with information on surveys for six-spotted (Cryptocephalus sexpunctatus) and ten-spotted (Cryptocephalus decemmaculatus) pot beetles
}

\author{
S. Burgess \\ Buglife, Balallan House, 24 Allan Park, Stirling FK8 2QG \\ E-mail: suzanne.burgess@buglife.org.uk
}

\begin{abstract}
Pot beetles (genus Cryptocephalus) are a fascinating group of beetles. Of the 19 species found in the U.K., 11 have been recorded in Scotland and seven of these have conservation designations. Buglife have successfully run public surveys in 2017, 2018 and 2019 for the sixspotted pot beetle (Cryptocephalus sexpunctatus) (Fig. 1) at Kirkconnell Flow, in Dumfries \& Galloway and the ten-spotted pot beetle ( $C$. decemmaculatus) (Fig. 2) at Black Wood of Rannoch in Perthshire. At Kirkconnell Flow, the six-spotted pot beetles were rediscovered during the first year of the survey in extremely low numbers, with a new colony found in the north of the site in 2019. At Black Wood of Rannoch, the ten-spotted pot beetle has now been recorded at three adjacent $1 \mathrm{~km}$ squares within the Camghouran area.
\end{abstract}

\section{INTRODUCTION}

Pot beetles are in the subfamily Cryptocephalinae (Order Coleoptera: Family Chrysomelidae). There are

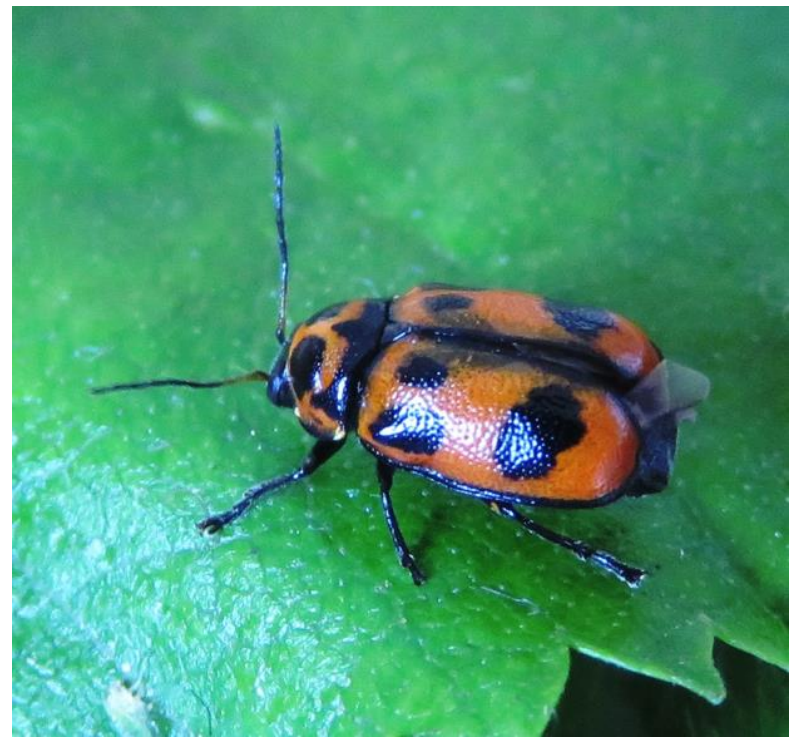

Fig. 1. Six-spotted pot beetle (Cryptocephalus sexpunctatus) at Kirkconnell Flow, Dumfries \& Galloway, Scotland. Length ca. $5 \mathrm{~mm}$. (Photo: S. Burgess)
19 species of pot beetle in the U.K. (Table 1), with the violet pot beetle (Cryptocephalus violaceus) recently being described as extinct and no longer on the U.K. species list (Hubble, 2014). At least 11 species are thought to occur in Scotland. Six of these have recent records on the National Biodiversity Network (NBN) Atlas and five have historic records that pre-date 1979 (Table 1).

Many species of pot beetle have suffered a decline in their distribution across the U.K. and are now quite rare. Six species are described as "Endangered" and two as "Vulnerable" in the most recent status review by Hubble (2014) (Table 1). Additionally, nine species are described as Nationally Rare and five as Nationally Scarce within Great Britain (Table 1). In Scotland, both the six-spotted pot beetle and the ten-spotted pot beetle are listed as a priority on the Scottish Biodiversity List (Table 1).

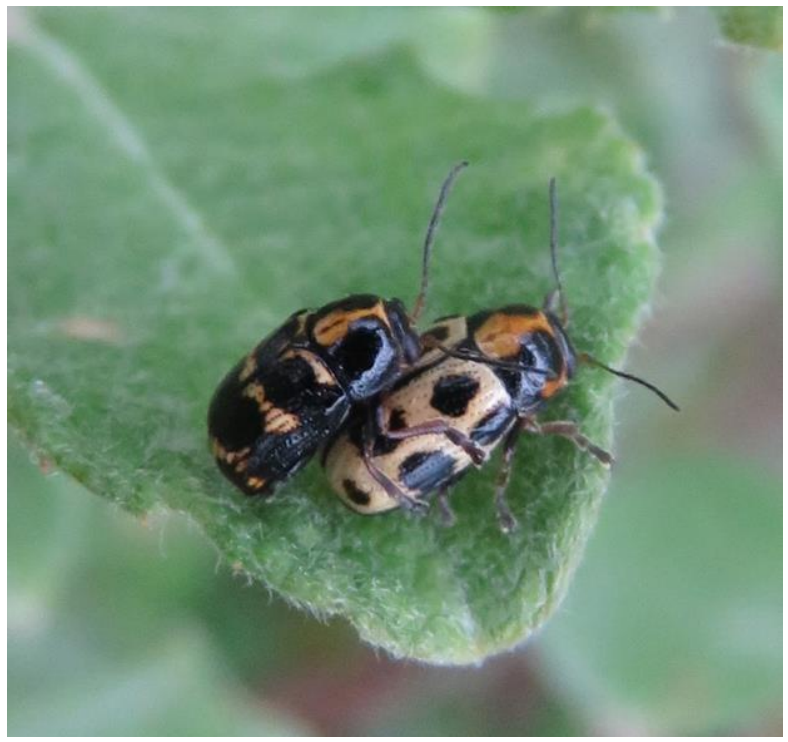

Fig. 2. Ten-spotted pot beetle (Cryptocephalus decemmaculatus) at Black Wood of Rannoch, Perthshire, Scotland. Length ca. $4 \mathrm{~mm}$. (Photo: S. Burgess) 


\begin{tabular}{|c|c|c|}
\hline Scientific Name & English Name & Notes \\
\hline $\begin{array}{l}\text { Cryptocephalus aureolus } \\
\text { (Suffrian, 1847) }\end{array}$ & & $\begin{array}{l}\text { Historic records and a more recent record from } 2015 \text { in } \\
\text { South Ayrshire. Rarity status: None, widespread across } \\
\text { U.K. }\end{array}$ \\
\hline $\begin{array}{l}\text { Cryptocephalus biguttatus } \\
\text { (Scopoli, 1763) }\end{array}$ & & Rarity status: VU, NR \\
\hline $\begin{array}{l}\text { Cryptocephalus bilineatus } \\
\text { (Linnaeus, 1767) }\end{array}$ & & Rarity status: LC, NS \\
\hline $\begin{array}{l}\text { Cryptocephalus bipunctatus } \\
\text { (Linnaeus, 1767) }\end{array}$ & Two-spotted pot beetle & $\begin{array}{l}\text { Historic records for this species from across Scotland. } \\
\text { Recorded at Kirkconnell Flow, Dumfries and } \\
\text { Galloway, SSSI in June 2017. Rarity status: LC, NS. }\end{array}$ \\
\hline $\begin{array}{l}\text { Cryptocephalus coryli } \\
\text { (Linnaeus, 1767) }\end{array}$ & Hazel pot beetle & $\begin{array}{l}\text { One record from Kincraig, Highland, from } 1946 . \text { No } \\
\text { recent records. Rarity status: EN, NR }\end{array}$ \\
\hline $\begin{array}{l}\text { Cryptocephalus } \\
\text { decemmaculatus (Linnaeus, } \\
1767 \text { ) }\end{array}$ & Ten-spotted pot beetle & $\begin{array}{l}\text { Recorded in Scotland at Black Wood of Loch } \\
\text { Rannoch, Perthshire, one site in England. Rarity status: } \\
\text { EN, NR, SBL }\end{array}$ \\
\hline $\begin{array}{l}\text { Cryptocephalus exiguus } \\
\text { (Schneider, 1792) }\end{array}$ & Pashford pot beetle & Rarity status: CR (PE), NR \\
\hline $\begin{array}{l}\text { Cryptocephalus frontalis } \\
\text { (Marsham, 1802) }\end{array}$ & & Rarity status: NT, NR \\
\hline $\begin{array}{l}\text { Cryptocephalus fulvus } \\
\text { (Goeze, 1777) }\end{array}$ & & $\begin{array}{l}\text { Not recorded from Scotland. Rarity status: None, } \\
\text { widespread in England and Wales. }\end{array}$ \\
\hline $\begin{array}{l}\text { Cryptocephalus hypochaeridis } \\
\text { (Linnaeus, 1758) }\end{array}$ & & Rarity status: LC, NS \\
\hline $\begin{array}{l}\text { Cryptocephalus labiatus } \\
\text { (Linnaeus, 1761) }\end{array}$ & Black birch pot beetle & $\begin{array}{l}\text { Recorded at several sites across Scotland. } \\
\text { Rarity status: None, widespread across the U.K. }\end{array}$ \\
\hline $\begin{array}{l}\text { Cryptocephalus moraei } \\
\text { (Linnaeus, 1758) }\end{array}$ & & $\begin{array}{l}\text { Pre-1979 record for site in North Ayrshire. No recent } \\
\text { records in Scotland. Rarity status: None, widespread in } \\
\text { England and Wales }\end{array}$ \\
\hline $\begin{array}{l}\text { Cryptocephalus nitidulus } \\
\text { (Fabricius, 1787) }\end{array}$ & Shining pot beetle & Rarity status: EN, NR \\
\hline $\begin{array}{l}\text { Cryptocephalus parvulus } \\
\text { (Müller, 1776) }\end{array}$ & & $\begin{array}{l}\text { At least two old records from pre-1979 in Scotland. } \\
\text { Rarity status: LC, NS. }\end{array}$ \\
\hline $\begin{array}{l}\text { Cryptocephalus primarius } \\
\text { (Harold, 1872) }\end{array}$ & Rock-rose pot beetle & $\begin{array}{l}\text { Records from Scotland from pre 1900s and none } \\
\text { shown on NBN Atlas. Rarity status: EN, NR. }\end{array}$ \\
\hline $\begin{array}{l}\text { Cryptocephalus punctiger } \\
\text { (Paykull, 1799) }\end{array}$ & Blue pepper-pot beetle & $\begin{array}{l}\text { At least two old records from pre-1979 in Scotland. No } \\
\text { recent records in Scotland. } \\
\text { Rarity status: VU, NR }\end{array}$ \\
\hline $\begin{array}{l}\text { Cryptocephalus pusillus } \\
\text { (Fabricius, 1777) }\end{array}$ & & $\begin{array}{l}\text { Recorded in Scotland in Dumfriesshire and Highlands. } \\
\text { Rarity status: None, widespread across England and } \\
\text { Wales. }\end{array}$ \\
\hline $\begin{array}{l}\text { Cryptocephalus quercetin } \\
\text { (Suffrian, 1848) }\end{array}$ & & Rarity status: EN, NR \\
\hline $\begin{array}{l}\text { Cryptocephalus sexpunctatus } \\
\text { (Linnaeus, 1758) }\end{array}$ & Six-spotted pot beetle & $\begin{array}{l}\text { Recorded in Scotland from Kirkconnell Flow NNR. } \\
\text { Rarity status: EN, NR, SBL }\end{array}$ \\
\hline
\end{tabular}

Table 1. List of Cryptocephalus pot beetles recorded in the U.K., with notes on when the species was described and those recorded in Scotland. Records taken from NBN Atlas and Cox (2007). Notes also include reference to rarity designations for each species as described by Natural England (Hubble, 2014) including (1) IUCN threat categories: CR (PE), Critically Endangered (Possibly Extinct); EN, Endangered; VU, Vulnerable; NT Near Threatened and Least Concern: LC; (2) Great Britain rarity: NR, Nationally Rare; NS, Nationally Scarce; and (3) whether the species is on the Scottish Biodiversity List: SBL. Scientific names in bold highlight species with records (either historic or more recent) from Scotland. 
Pot beetles get their English name from the protective shell-like cocoon or "pot" that the larvae inhabit. The pots are initially built by the female during and immediately after egg laying, with the egg being held between the rear metatarsi and covered by the female's faeces. Once covered, the pots are dropped to the ground amongst leaf litter and this forms much of the larval diet. The structure of the pot varies between the different species of pot beetle. When the egg hatches, the larva makes a hole at one end of the pot allowing it to feed and move around in the leaf litter. As the larva grows, the pot needs to be enlarged which it does using its own faeces. The larvae can take up to two years to develop into adults (Hubble, 2017).

Another key feature of this group is that the head of the adults is hidden under their bulging pronotum and is the source of the scientific name for the genus Cryptocephalus, which means "hidden head".

Similar to many of their leaf beetle relatives, adult pot beetles are typically found feeding on the leaves of their host plant and if disturbed feign death (thanatosis) and drop to the ground.

\section{SIX-SPOTTED POT BEETLE}

The six-spotted pot beetle (C. sexpunctatus) (Fig. 1) was once widespread in southern England with scattered records as far north as Ayrshire in Scotland (Piper, 2002; Anon., 2010; C. Barnes, pers. comm.). The current status of the beetle is that it now has an extremely localised distribution in the U.K. with recent records in Scotland from Kirkconnell Flow, Dumfries \& Galloway, and most recently in May 2020 from two new areas in Dumfries \& Galloway near Kirkton (NX972820) and at Racks Moss (NY03247407). The beetle has been recorded at two sites in England, at Stockbridge Down in Hampshire and a recent discovery of a population in Lincolnshire at Stockbridge Down, despite repeated searches, only a few individuals have been recorded since 1990 .

The six-spotted pot beetle has a reddish-yellow thorax and elytra with usually three black spots (sometimes four) on each elytral wing case (Fig. 1). Adult beetles are 4.5-6.5 $\mathrm{mm}$ in length (Hubble, 2012). This species has been recorded feeding on leaves of the saplings of aspen (Populus tremula), crack willow (Salix fragilis), hawthorn (Crataegus monogyna), oak (Quercus spp.) and birch (Betula spp.). Adults have also been recorded on the flowers of wood spurge (Euphorbia amygdaloides) and yellow Asteraceae species (Cox, 2007).

\section{TEN-SPOTTED POT BEETLE}

Only two sites are currently known to support tenspotted pot beetles ( $C$. decemmaculatus) in the U.K. Wybunbury Moss National Nature Reserve (NNR) in Cheshire, and Camghouran on the south side of Loch Rannoch within the Black Wood of Rannoch in Perthshire (Piper \& Compton, 2013; Piper, 2013, 2015). Single specimens have previously been recorded from two other sites in Scotland, both in Aberdeenshire: one at Muir of Dinnet (designated as a National Nature Reserve (NNR), Special Area of Conservation (SAC) and Site of Special Scientific Interest (SSSI)) in 1986; and the other within Morrone Birkwood Nature Reserve (also designated as a NNR, SAC and SSSI) in Braemar in 1959. However, the exact locations within both sites is unknown (Littlewood \& Stockan, 2013).

The ten-spotted pot beetle (Fig. 2) has five black spots on each yellow-orange elytron and a black pronotum with a distinctive central yellow mark (Cox, 2007; Hubble, 2012). The markings of this species are highly variable, displaying a range of spot sizes. Melanic forms, known as subspecies $C$. decemmaculatus bothnicus, with completely black elytra but retaining the yellow mark on the pronotum, have been widely recorded in the U.K. (Piper, 2002); around 30\% of both male and female individuals found at Camghouran at Loch Rannoch in 2017 displayed this colour form (Burgess \& Shanks, 2017).

Females of this species have relatively shorter prothoracic limbs and antennae than males and are often slightly bulkier reaching $4 \mathrm{~mm}$ in length, whereas males generally reach $3 \mathrm{~mm}$ (Hubble, 2012).

The ten-spotted pot beetle feeds on the leaves of willow (Salix spp.) growing in sheltered Sphagnum-covered heathland habitat on hillsides on the edges of quaking bogs. Favoured host plants in Scotland appear to be small specimens (under $2 \mathrm{~m}$ tall) of eared willow (Salix aurita) but they have been recorded in England from grey willow ( $S$. cinerea), goat willow ( $S$. caprea), and occasionally downy birch (Betula pubescens) (Cox, 2007).

\section{POT BEETLE SURVEYS \\ Background}

Buglife ran surveys for the six-spotted and ten-spotted pot beetles during early summer in 2017, 2018 and 2019 (Table 2). The surveys were advertised to members of the public and during the day attendees were provided with training on:

(1) how to survey for invertebrates (with a focus on pot beetles and their leaf beetle relatives) using sweep nets and through direct observation;

(2) how to identify invertebrates observed and collected through sweep nets and pots;

(3) the importance of monitoring sites;

(4) the importance of the habitats at the site being surveyed for invertebrates and other wildlife; and

(5) how to record invertebrates.

Each attendee was provided with a sweep net and pots. Attendees were also shown the target plant for the pot beetle species (see below for more information on host plants for each pot beetle species surveyed), and to focus attention on surveying saplings of these tree species that were less than $2 \mathrm{~m}$ in height. 


\begin{tabular}{lll}
\hline Year & $\begin{array}{l}\text { Kirkconnell Flow } \\
\text { six-spotted pot beetle }\end{array}$ & $\begin{array}{l}\text { Black Wood of Rannoch } \\
\text { ten-spotted pot beetle }\end{array}$ \\
\hline $\mathbf{2 0 1 7}$ & 23rd, 24th June 2017 & 1st July 2017 \\
$\mathbf{2 0 1 8}$ & 22nd, 23rd June 2018 & 7th, 8th July 2018 \\
$\mathbf{2 0 1 9}$ & 21st, 22nd June 2019 & 3rd, 4th July 2019 \\
\hline
\end{tabular}

Table 2. Dates on which Kirkconnell Flow, Dumfries \& Galloway and Black Wood of Rannoch, Perthshire, both Scotland, were visited in 2017,2018 and 2019 to survey for pot beetles.

\section{Survey at Kirkconnell Flow}

Located $6 \mathrm{~km}$ south of Dumfries, Dumfries \& Galloway, Kirkconnell Flow is a raised bog that lies on the flood plain of the River Nith and is designated as a SSSI and SAC. Permission to run the surveys and collect invertebrates with members of the public was granted by Scottish Natural Heritage (SNH) who own and manage this Nature Reserve. Areas surveyed within this site for the beetle each year focused on small trees found along the edges of the footpath that leads from the car park into the raised bog, as well as on small trees along the edge of the bog itself and found elsewhere on the site.

In 2017 two adults of the six-spotted pot beetle were recorded along the main footpath leading to the raised bog from the car park at grid reference NX96437020. These were the first two individuals of this species to have been recorded in Scotland since the late 1990s (Burgess \& Shanks, 2017). In 2018 the area was revisited with volunteers to look for the beetles in new areas of the Nature Reserve with an aim to determine the health of the population. No species of pot beetles were recorded that year (Lemon \& Shanks, 2019). As only two adults of this species were recorded during the first two years of the project it was important to revisit Kirkconnell Flow in 2019. During two survey days in 2019 (Table 2), a total of 17 adult six-spotted pot beetles was recorded at Kirkconnell Flow; two individuals were found along the main footpath at separate locations at grid reference NX96297017 and NX96357020, and a further 15 adults were recorded at NX96337048; this area was identified by SNH staff as potentially having habitat that would support a population of the beetles and is a new area identified for the species (Burgess \& Lindsay, 2019).

During the surveys it was observed that adults of the sixspotted pot beetle appear to favour the saplings of silver birch (Betula pendula) which are plentiful along the edges of the main footpath and raised bog at Kirkconnell Flow and within the open area discovered in 2019 (Burgess \& Lindsay, 2019). Only adults were recorded during the surveys and only from silver birch, although there are saplings available of other tree species.

Two other species of pot beetle were recorded at Kirkconnell Flow during the surveys, the common black birch pot beetle (C. labiatus) (in 2017 and 2019) and two adults of the Nationally Scarce in Great Britain twospotted pot beetle (C. bipunctatus) (in 2017 only) (Burgess \& Shanks, 2017; Burgess \& Lindsay, 2019).

\section{Survey at Black Wood of Rannoch}

The Black Wood of Rannoch is an area of ancient woodland growing along the south shore of Loch Rannoch in Perthshire, the area is designated as a SSSI and SAC. The ten-spotted pot beetles have previously been recorded within the Camghouran area at Black Wood of Rannoch and this area was the focus during each survey to determine the distribution and health of the population. Permission to run the surveys and collect invertebrates with volunteers was granted by the landowners through SNH.

During the first survey in 2017 (Table 2), effort was focused on surveying the last place the beetles had been recorded at grid reference NN544557. In this area, several adults were observed in a clearing approximately $6 \mathrm{~m}^{2}$ in area (Burgess \& Shanks, 2017). In 2018 this area was revisited (Table 2) and several adults were found within three separate areas of grid reference NN545557 (Lemon \& Shanks, 2019). Several adults were then discovered in three areas of a new $1 \mathrm{~km}$ square at NN542566 (Lemon \& Shanks, 2019). In 2019 the new area where beetles were discovered in 2018 (at NN542566) was visited and over 40 adults were counted (Burgess \& Lindsay, 2019). A new $1 \mathrm{~km}$ square was visited in 2019 at NN5356 and a handful of adults was counted within two areas at NN53835681 and NN53345698 (Burgess \& Lindsay, 2019). In view of the terrain it is very possible that the ten-spotted pot beetles are found across a wider area of the Black Wood of Rannoch. It was noted that they appear to favour saplings of eared willow that is less than $1.5 \mathrm{~m}$ in height and in open areas. The largest population observed within grid reference NN542566 appear to be doing well; this could be because the area is a wayleave for electricity pylons that is cleared every several years allowing for eared willow to regenerate, and so providing young saplings for the beetles to feed from.

Two species of pot beetle were recorded during the surveys at Black Wood of Rannoch, the common black birch pot beetle and Clytra quadripunctata (not strictly a pot beetle but included within the pot beetle subfamily), which is associated with the nests of wood ants (Formica spp.) and appears to be a new record for the area (Burgess \& Lindsay, 2019).

\section{CONCLUSION}

Both the six-spotted and ten-spotted pot beetles are described as "Endangered" in the most recent International Union for Conservation of Nature (IUCN) status review (Hubble, 2014) and both are listed as a priority on the Scottish Biodiversity List. Both species are currently only known from one site each in Scotland, although they do have historical records that are worth investigating in future surveys. These surveys have 
successfully found both target species with the help of volunteers and have recorded other species of invertebrates at both sites. Reports have been produced each year that have provided information on the surveys and recommendations on habitat management if needed, and future surveys to ensure the long-term survival of both species in Scotland. These reports are available on the Buglife website: www.buglife.org.uk.

\section{ACKNOWLEDGEMENTS}

Buglife would like to thank Scottish Natural Heritage for providing funding to allow surveys for both species that have helped rediscover these very rare species in Scotland. We would also like to thank all the volunteers who have participated in the surveys.

\section{REFERENCES}

Anon. (2010). UK Priority Species Pages. Version 2: Six-spotted Pot Beetle Cryptocephalus sexpunctatus. Joint Nature Conservation Committee, Peterborough. http://jncc.defra.gov.uk/_speciespages/251.pdf Accessed 15th April 2020.

Burgess, S. \& Lindsay, J. (2019). Spotting Pot Beetles: Survey Report and Habitat Recommendations. Buglife.

https://cdn.buglife.org.uk/2019/11/Spotting-potbeetle-survey-report-2019-final.pdf Accessed 15th April 2020.

Burgess, S. \& Shanks, S. (2017). Spotting Pot Beetles: Survey Report and Habitat Recommendations. Buglife. https://cdn.buglife.org.uk/2019/07/Spotting-potbeetle-survey-report-final_0.pdf Accessed 15th April 2020.

Cox, M.L. (2007). Atlas of the Seed and Leaf Beetles of Great Britain and Ireland. Pisces Publications, Newbury.

Hubble, D. (2012). Key to the Adults of Seed and Leaf Beetles of Britain and Ireland. Field Studies Council, Shrewsbury.

Hubble, D. (2014). A Review of the Scarce and Threatened Beetles of Great Britain: the Leaf Beetles and their Allies, Chrysomelidae, Megalopodidae and Orsodacnidae. Natural England Species Status No. 19.

http://publications.naturalengland.org.uk/file/62448 84977549312 Accessed 15th April 2020.

Hubble, D. (2017). Leaf Beetles. Naturalists' Handbooks No. 34. Pelagic Publishing, Exeter.

Lemon, A. \& Shanks, S. (2019). Spotting Pot Beetles: Survey Report and Habitat Recommendations. Buglife.

https://cdn.buglife.org.uk/2019/07/Spotting-potbeetle-survey-report-2018-final.pdf Accessed 15th April 2020.

Littlewood, N.A. \& Stockan, J.A. (2013). Surveillance of Priority Terrestrial Invertebrates in Scotland. Scottish Natural Heritage Commissioned Report No. 609.

Piper, R.W. (2002). Conservation Biology of Cryptocephalus Species and Other Threatened UK Beetles. Ph.D. thesis, University of Leeds.
www.rosspiper.net/wp-content/uploads/2013/05/Ro ss-Piper-PhD-thesis-2002.pdf Accessed 15th April 2020.

Piper, R.W. (2013). Cryptocephalus decemmaculatus at Wybunbury Moss, Cheshire. Natural England Research Reports.

Piper, R.W. (2015) Cryptocephalus decemmaculatus at Wybunbury Moss, Cheshire. Natural England Research Reports.

Piper, R.W. \& Compton, S.G. (2013). How limited is dispersal in the rare beetle, Cryptocephalus decemmaculatus (Chrysomelidae, Cryptocephalinae)? Journal of Insect Conservation 17, 12291235 .

https://doi.org/10.1007/s10841-013-9604-6 